\title{
A general framework for selecting work participation outcomes in intervention studies among persons with health problems.
}

\section{Margarita Ravinskaya (D m.ravinskaya@amsterdamumc.nl)}

Amsterdam UMC, location Academic Medical Center, University of Amsterdam, Coronel Institute of Occupational Health, Amsterdam Public Health research institute

\section{Jos H. Verbeek}

Amsterdam UMC, location Academic Medical Center, University of Amsterdam, Coronel Institute of Occupational Health, Amsterdam Public Health research institute

\section{Miranda W. Langendam}

- Amsterdam UMC, location Academic Medical Center, University of Amsterdam, Department Epidemiology and Data Science, Amsterdam Public Health research institute

\section{Ira Madan}

Guy's and St Thomas' NHS Trust and Faculty of Life Sciences and Medicine, King's College London

\section{Suzanne M.M. Verstappen}

Centre for Epidemiology Versus Arthritis, Faculty of Biology, Medicine and Health, The University of Manchester

\section{Carel T.J. Hulshof}

Amsterdam UMC, location Academic Medical Center, University of Amsterdam, Coronel Institute of Occupational Health, Amsterdam Public Health research institute

\section{Jan L. Hoving}

Amsterdam UMC, location Academic Medical Center, University of Amsterdam, Coronel Institute of Occupational Health, Amsterdam Public Health research institute

\section{Regina Kunz}

Academic Unit EbIM, Evidence Based Insurance Medicine, Department of Clinical Research, University of Basel

\section{Research Article}

Keywords: work participation, return to work, sick leave, occupational functioning, work ability, outcome measurement, occupational health, vocational rehabilitation, research framework, core outcome set

Posted Date: February 25th, 2022

DOI: https://doi.org/10.21203/rs.3.rs-1342930/v1

License: (c) (i) This work is licensed under a Creative Commons Attribution 4.0 International License. Read Full License 


\section{Abstract}

Background: Work participation is important for health and can be considered as engagement in a major area of life which is of significance for most people, but it can also be thought of as fulfilling or discharging a role. Currently, academic research lacks a comprehensive classification of work participation outcomes. The International Classification of Functioning is the foremost model in defining work functioning and its counterpart work disability, but it does not provide a critical (core) set of outcomes. It is important to standardize the definitions and the nomenclature used in the research of work participation, so that the outcomes of studies are comparable, and practitioners and guideline developers can better decide what works best. As work participation is a broad umbrella term including outcome categories which need unambiguous differentiation, a framework needs to be developed first.

Aim: To propose a framework which can be used to develop a generic core outcome set for work participation.

Methods: First, we performed a systematic literature search on the concept of (work) participation, perspectives on how to measure it, and existing classifications for outcome measurements. Next, we derived criteria for the framework and proposed a framework based on the criteria. Last, we applied the framework to six case studies as a proof of concept.

Results: Our literature search provided 2106 hits and we used 59 studies for full-text analysis. Based on the literature and the developed criteria we propose four overarching outcome categories: (1) initiating employment, (2) having employment, (3) increasing or maintaining productivity at work and (4) return to employment. These categories appeared feasible in our proofof-concept assessment with six different case studies.

Conclusion: We propose to use the framework for work participation outcomes to develop a core outcome set for intervention studies to improve work participation.

\section{Introduction}

According to the World Disability Report of 2011, about 978 million adults experience a form of disability which impairs their functioning in daily life. Having a disability may have a negative impact on well-being due to associated social isolation, poor mental health and strained family relationships. Societal repercussions include government expenditure on disability benefits, reduced work capacity in terms of attendance and productivity and early retirement schemes which in total may account for $\sim 2 \%$ of GDP in OECD countries (1). Even though paid work participation is a concern on the socioeconomic level, it is particularly important in the fields of rehabilitation and occupational health. In research, much effort is directed at interventions to increase work participation in people with ill health (2).

Systematic reviews provide insight into which interventions are beneficial and help guide future guidelines, practice and policy. However, researchers and authors of systematic reviews on work participation in relation to health have reported the challenges of heterogeneous outcome measurement in trials which impedes large-scale evidence comparison (3-7). Variability in the use of terminology is one of the reasons why comparison is currently difficult. Work participation and work disability are not clearly defined terms and are used with varying meanings. To resolve communication issues, the WHO developed the International Classification of Functioning, Disability and Health (ICF) (8). In the ICF, participation in general is defined as involvement in a life situation. Work and employment are major life situations in which people should be able to participate in spite of ill health. (9). Following Alheresh and Keysor's interpretation of the ICF (10), work functioning is defined as an overarching term for work activities and work participation, and work disability as a limitation of work activities or a restriction of work participation. This makes work disability a broad term denoting that people with impaired health have difficulty in performing work related tasks or maintaining employment.

Although vocational rehabilitation and occupational health fields use different terms, the aims and general content of interventions are the same. However, clear distinctions need to be made for outcome categories. Studies evaluating the effects of drug therapy on work productivity require different work outcome measures than studies evaluating supported

Page $2 / 20$ 
employment interventions enabling unemployed people to enter the job market. We have previously shown extensive variability in the use of outcome measurements across studies evaluating work outcomes (11).

Core Outcome Sets (COS) are recommended as a solution to heterogeneous outcome measurements (12). A COS is an agreed set of minimum outcomes which should be measured in all trials in a specific health area. Only the consistent use of COS will allow large-scale pooling of outcomes and decrease outcome reporting bias (13). One of the most prominent examples of the development of a COS is the Outcome Measures in Rheumatology Initiative (OMERACT). Over the past 30 years, a group of researchers in the field of rheumatology has worked on recommending or developing a range of outcome measurements including work participation for people with rheumatic and musculoskeletal diseases (14). Due to this initiative, unambiguous outcome reporting of RCTs within rheumatology has considerably improved $(12,15)$.

Many authors have discussed conceptual issues of measuring work participation through a range of perspectives, but no overview exists (16-20). To date, no COS exists for work participation outcomes that can be used for intervention studies (vocational and non-vocational) to improve work participation for people experiencing health problems. To that end, we started a project to develop a generic COS for work participation (http://www.cosforwork.org/). Prior to developing a COS it is important to understand which factors are key to consider when selecting and measuring work participation outcomes. In this initial stage of the COS development, we aim to propose a framework which can be used for the development of the generic cos.

The objectives of this paper are:

i) to provide an overview of theoretical perspectives on work participation interventions and their outcome measurements, ii) to evaluate existing literature on classification of work participation outcomes, iii) to derive criteria for classification of work participation outcomes, and iv) propose a framework which helps inform the selection of work participation outcomes and test the framework as a proof of concept.

\section{Methods}

First, we conducted a systematic search of the literature to find studies on definitions or classifications of work participation outcomes (Fig. 1). To identify relevant articles, we used the following eligibility criteria: the study should focus on (1) people who either work or want to work (more), (2) change in work participation due to an intervention, and (3) any kind of theory, framework, model or categorization of work participation outcomes or elements of work participation, and constructed a search strategy in MEDLINE (PubMed)) (Appendix 1) and searched up to 22/10/2021. We searched Google with the terms: sick leave, sickness absence, work ability, disability in combination with theory, concept or classification. We explored the first 20 hits further. In addition, we searched our personal files for relevant studies. One author (JV) removed references that did not fulfil the inclusion criteria. Three authors (MR, JV, JH) then selected references for full-text assessment and inclusion based on the full text. We extracted data on whether the article described a classification, the name of the classification, and the specific classification or outcome addressed.

We evaluated what can be learned from studies which define (work) participation in general, from classifications of work outcomes and from current definitions of specific work outcomes. All authors participated in group discussions and provided written commentary to create criteria for the framework. We took elements of the theories discussed in this paper, the scope of the COS and the criteria, and built these into a new framework which served as a point of departure for the selection of work participation outcomes in a COS.

Finally, as a proof of concept we applied the framework as a case study to six randomized controlled trials (RCT's) which we believe constitute a representative variety of short-term, long-term, and intermittent conditions and stages of work participation. 
Regarding terminology, we refer to an outcome as the endpoint of a trial that is expected to change, such as symptoms, sick leave or return to work. We define an outcome measurement method as the way in which the outcome is measured e.g., through interviews, self-report, data collection from registries or questionnaires. Outcome measurement instruments are instruments which are used to measure the specific outcome, such as validated or self-constructed questions/items or questionnaires.

\section{Results}

The search in MEDLINE (PubMed) yielded 2106 references, of which 296 were considered relevant. Most of the 1810 irrelevant references were about the application of the ICF for a specific disease and not about work participation. An additional 60 references were found through the Google search or from our personal files. After screening these 356 references, we selected 67 for full-text analysis and included 59 articles. Fifteen studies provided a theoretical perspective of participation based on the ICF (part A). A further 36 studies described how effectiveness of work participation interventions should be measured (part B). In addition, eight studies provided a classification of work participation outcomes (part C). Based on the reviewed literature and the scope of our COS we found six mandatory criteria and two optional criteria which should be met by the framework (part D). The framework includes four distinct work participation stages with relevant outcomes belonging to each stage (part E). In a proof of concept a sufficient match could be made with work outcomes from six RCT's and the criteria for the framework (part F).

\section{A. Perspectives on the concept of participation: "The International Classification of Functioning"}

\section{The International Classification of Functioning}

The ICF, approved for use by the WHO in 2001 (21) constitutes the predominant theoretical classification of societal participation among individuals with health problems. The model is valued and broadly adopted due to its universality, comprehensiveness (22) and the capability to consider disability through a biopsychosocial perspective (23).

The ICF specifies components of disability and health, with impairments in body structures or functions on one side, and activity limitations and participation restriction on the other. These components are influenced by environmental and personal factors (Fig. 2). Activity is seen as the execution of a task and participation as involvement in a life situation. Activities and participation can be assessed either on the level of having the general capacity to do an activity in a standardized environment or as actual performance within the context of their daily life.

However, the scientific community finds that the ICF is too ambiguous and incomprehensive for informing how to measure participation - its definitions do not ensure that activities and participation are mutually exclusive $(24,25)$. It lacks the subjective aspect of participation (for example: satisfaction) $(26,27)$ and existing measurement instruments based on the ICF contain only very general questions about (work) participation $(28,29)$. Moreover, the ICF codes within the (sub-) chapters do not explain the dynamics between health states, functions and how changes occur over time in the context of work participation $(23,30)$.

The ICF does not address the normative character of participation. Participation can be seen as performing or discharging a social role (31-34), but there is not a universal standard for a "normal" level of participation. The worker role is clearly distinct from other social roles (35). Paid work which is the focus of this project differs from volunteering work and has different normative aspects which should be considered in terms of outcome measurement.

ICF Core Sets are made to narrow down the list of about 1400 categories to the what is most relevant to consider in practice or research for a specific setting or health problem (36). However, such sets are not made exclusively for core outcome measurements in research and would still contain too many items. A Core Outcome Set must represent a minimum set of outcomes which are feasible and relevant to measure across all trials within a specific health field (13). 


\section{B. Perspectives on measuring work participation}

General work participation and disability evaluation

Work participation is influenced by personal and environmental factors, such as motivation, the work environment, and national policies. Outcomes domains or stages of work participation which are most important to measure are contextspecific. A summary of theories proposing how to capture (effectiveness) results of work participation interventions can be found in Table 1. We found that the ICF is used as a predominant point of reference, but no final recommendations are made on specific critical outcomes or measurement instruments which could be used for a generic COS for Work.

Table 1

Perspectives of theories and models on measuring general work participation

\section{Theory/model/author Focus of the Perspective on measuring work participation manuscripts}

Momsen et al (37) Operationalize Use of ICF can be operationalized in vocational rehabilitation but more

2019

ICF for research is needed for standardization.

vocational

rehabilitation.

Jetha et al (38)

\section{Capture the} complexity of

2016

$$
\text { work disability }
$$
research.

System dynamics modelling should be applied to work participation research. Dynamic behaviours between individual, psychosocial, organizational and regulatory components need to be seen in terms of feedback loops rather than a linear process. However, this would be a time consuming and complex.

Mateen et al (39) 2017, Review existing

Sternberg \& Bethge (40) 2018

Mehnert et al (41) 2013 work outcome measures.

Identify which

Evaluation of a broad range of instruments measuring work participation based on their psychometric properties. No final recommendations could be made. work outcomes are most important to measure for cancer survivor.

Combs \& Heaton (42), 2016

Sandqvist \& Henriksson (43) 2004

\section{Conceptual} analysis of work functioning and what is important to measure.

Describes measuring (partial) disability.
Based on existing frameworks, the following outcomes are important for cancer survivors: employment, return to work, work ability, work performance, job opportunities, income, work satisfaction, job promotion and training and sustainability in work retention.
Anner et al (23) 2012, Goldman (44) 2013, Marfeo et al (45) 2013, Berglind \& Gerner (46) 2002, Iwanaga et al (47) 2019
Describe how policy changes impact transitions between employment states
Work participation should be seen through a holistic lens with most important components closely related to the structure of ICF.

\begin{abstract}
Recommendations are made on disability evaluation. The ICF can be incorporated in the evaluation. Motivation and self-efficacy are important to include in disability evaluation as they are predictors of work participation.
\end{abstract}

Kim \& Rhee (48) 2018

Prevalent work participation outcomes

We reviewed literature on specific types of work participation outcomes/constructs and which methodological issues should be considered. Here, we list the most prevalent types of outcomes discussed in literature. Sickness absenteeism can be defined as the decision or inability to not attend work due to an illness. The decision process is phased over time and may be 
influenced by the supervisor-subordinate relationship, individual capacities and incentives (49-51). Return to work (RtW) is influenced by factors which may differ for the stakeholders involved. Second, in terms of RtW measurements, aspects like sensitivity to change and validity (example: first RtW measured as standalone measure) need to be considered $(19,52-58)$. Productivity is often measured by a combination of several outcomes, such as employment status, absenteeism and presenteeism. While presenteeism is an outcome gaining more attention for evaluating productivity, consensus is currently lacking on how to best measure it. Generic work performance measurements may include measures such as task performance, counterproductive work behaviour and adaptive performance (59-66). Work ability is another prevalent concept, seen as self-perceived potential for work participation, and is measured mainly on the level capacity rather than performance (67-70).

\section{Classification of work participation outcomes}

Of the eight studies which provided a classification of recommended outcomes and measures for work participation one took a broad approach (17), five $(10,27,36,71,72)$ used the ICF items and two looked at productivity (73) and absenteeism (16) separately (Table 2). A meaningful general classification of work capacity outcomes may require considerations such as the aim of the study which frequently revolve around the effectiveness of an intervention and the perspective of the study, i.e., employer, worker or society. In terms of using the ICF to operationalize work participation outcomes, a proposal is made to use work functioning as the overarching term for work activities, such as driving, and work participation for maintaining desired employment. Work disability may denote limitations on work activities, such as difficulty in driving, and participation restrictions, such as number of hours lost from work. The relationship between participation and disability can be influenced by contextual factors, and people can move in and out of limitations and restrictions over time. Restrictions on work participation encompasses all restrictions on work roles varying from work productivity to employment status, career advancement and job opportunities (10).

Researchers have proposed varying lists of ICF items $(27,36,71)$ and measurement instruments that could be used to measure a core set of ICF items for vocational rehabilitation (72). However, these lists address a broad spectrum of issues related to vocational rehabilitation beyond outcomes that measure the effectiveness of interventions and do not intend to be a classification of outcomes to be used in trials.

A recent (2016) COS for rheumatoid arthritis evaluated measurement instruments for at-work productivity loss which includes absenteeism and presenteeism, measured as 'number of days or hours off work', or difficulties at work, respectively (73). However, currently there is no agreement on a measure of presenteeism which is underpinned by economic theory $(63,74$, 75). For measuring sick leave, five measures have been suggested: frequency, length, incidence rate, cumulative incidence and duration of sick leave spells $(16,76,77)$. 
Table 2

Current classifications for work participation outcomes. Here, we report the primary aim, the results of each study and the stakeholder perspective $(\mathrm{N}=(8)$

\begin{tabular}{|c|c|c|c|c|}
\hline Outcome & Study & Aim & Results & Perspective \\
\hline \multirow[t]{6}{*}{$\begin{array}{l}\text { Work } \\
\text { participation }\end{array}$} & $\begin{array}{l}\text { Amick et } \\
\text { al (17) } \\
2000\end{array}$ & $\begin{array}{l}\text { To review } \\
\text { and illustrate } \\
\text { a sample of } \\
\text { work } \\
\text { outcome } \\
\text { measures }\end{array}$ & $\begin{array}{l}\text { Five reasons and measures for work outcomes: } 1 \text {. } \\
\text { productivity loss in clinical trials } 2 \text {. effects of health } \\
\text { services } 3 \text {. effects of injury prevention } 4 \text {. effects of } \\
\text { work reorganization such as ergonomic changes } 5 \text {. } \\
\text { improve provider-worker interaction }\end{array}$ & $\begin{array}{l}\text { Worker, } \\
\text { employer, } \\
\text { societal, } \\
\text { economic }\end{array}$ \\
\hline & $\begin{array}{l}\text { Alheresh } \\
\text { et al (10) } \\
2015\end{array}$ & $\begin{array}{l}\text { To organize } \\
\text { and define } \\
\text { work } \\
\text { participation } \\
\text { outcomes } \\
\text { based on ICF }\end{array}$ & $\begin{array}{l}\text { Defined disability, activity, participation, activity } \\
\text { limitations, participation restrictions }\end{array}$ & $\begin{array}{l}\text { Worker, } \\
\text { employer, } \\
\text { societal, } \\
\text { economic }\end{array}$ \\
\hline & $\begin{array}{l}\text { Escorpizo } \\
\text { et al (71) } \\
2011\end{array}$ & $\begin{array}{l}\text { To list of ICF } \\
\text { items } \\
\text { important for } \\
\text { vocational } \\
\text { rehabilitation }\end{array}$ & $\begin{array}{l}101 \text { ICF categories are listed as important for work } \\
\text { participation: } 22 \text { for body functions, } 13 \text { for body } \\
\text { structures, } 36 \text { for activities and participation, and } 30 \text { for } \\
\text { environmental factors }\end{array}$ & Healthcare \\
\hline & $\begin{array}{l}\text { Finger et } \\
\text { al (36) } \\
2012\end{array}$ & $\begin{array}{l}\text { Brief ICF core } \\
\text { set important } \\
\text { for } \\
\text { vocational } \\
\text { rehabilitation }\end{array}$ & $\begin{array}{l}\text { Consensus about brief Core Set including } 13 \text { ICF items: } \\
6 \text { activities and participation, } 4 \text { environmental factors, } \\
3 \text { body functions }\end{array}$ & Healthcare \\
\hline & $\begin{array}{l}\text { Glässel et } \\
\text { al (27) } \\
2011\end{array}$ & $\begin{array}{l}\text { List ICF items } \\
\text { important for } \\
\text { patients in } \\
\text { vocational } \\
\text { rehabilitation }\end{array}$ & $\begin{array}{l}\text { List contains } 160 \text { ICF categories. ICF components (a) } \\
\text { body functions, (b) activities and participation and (c) } \\
\text { environmental factors were equally represented, while } \\
\text { (d) body structures appeared less frequently }\end{array}$ & Worker \\
\hline & $\begin{array}{l}\text { Luna et } \\
\text { al }(72) \\
2020\end{array}$ & $\begin{array}{l}\text { Find } \\
\text { measurement } \\
\text { instruments } \\
\text { for ICF core } \\
\text { set for } \\
\text { vocational } \\
\text { rehabilitation }\end{array}$ & $\begin{array}{l}13 \text { instruments covered } 58 \text { categories ( } 64.5 \%) \text { of the } \\
\text { core set: } 13(76.5 \%) \text { of the body functions component, } \\
29(72.5 \%) \text { of the activities and participation } \\
\text { component and } 16(49 \%) \text { environmental factors }\end{array}$ & Worker \\
\hline Productivity & $\begin{array}{l}\text { Beaton et } \\
\text { al (73) } \\
2016\end{array}$ & $\begin{array}{l}\text { To } \\
\text { recommend } \\
\text { OMERACT } \\
\text { productivity } \\
\text { measures for } \\
\text { Rheumatoid } \\
\text { Arthritis }\end{array}$ & $\begin{array}{l}\text { Provisional recommendations: WALS (Workplace } \\
\text { Activity Limitations Scale), WLQ-25 PDmod (Work } \\
\text { Limitations Questionnaire with modified physical } \\
\text { demands scale), WAI (Work Ability Index), WPS } \\
\text { (Arthritis-specific Work Productivity Survey), and WPAI } \\
\text { (Work Productivity and Activity Impairment } \\
\text { Questionnaire) }\end{array}$ & $\begin{array}{l}\text { Patient, } \\
\text { economic }\end{array}$ \\
\hline Absenteeism & $\begin{array}{l}\text { Hensing } \\
\text { et al (16) } \\
1998\end{array}$ & $\begin{array}{l}\text { Examine sick } \\
\text { leave } \\
\text { measures } \\
\text { used in } \\
\text { research }\end{array}$ & $\begin{array}{l}\text { Five measures are recommended: frequency, length, } \\
\text { incidence rate, cumulative incidence and duration of } \\
\text { sick leave spells. }\end{array}$ & Epidemiological \\
\hline
\end{tabular}

\section{Criteria of the framework for work participation outcomes}

Based on our points of departure; the scope of our COS, recommendations by the COMET initiative and the findings of studies discussed above we conclude that work participation outcomes for a COS to be applied in intervention studies should be informed by several criteria. We held several meetings within our research team to improve the terminology, evaluate priorities and discuss the feasibility of these criteria. Our discussions resulted in the conclusion that not all criteria are equally relevant and feasible to measure for interventions with varying aims. Therefore we propose a distinction between mandatory and optional criteria (Table 3). In addition, the outcome measures should be able to capture the transitions in the work 
participation process over time $(50,58)$ that can be used in studies of people with a health problem who seek work, are absent from work, or who are at risk of losing their work. This criterion applies to the COS as a whole, as no single outcome can capture the above mentioned transitions between work phases.

Mandatory criteria that should apply to outcomes measured in every study:

1. The outcomes should inform about the effects of interventions aimed to positively affect work participation compared to no intervention or alternative interventions. This implies that the measures of the outcomes need to be sensitive to change $(58,78)$ and be applicable for vocational and non-vocational intervention studies.

2. The outcomes should represent a minimum set which are feasible to measure in all intervention studies (13).

3. The outcomes should be applicable internationally.

4. The outcomes should specifically aim for work participation rather than 'societal participation' in general terms. They should relate to paid work to address the specific factors of the worker role which are not transferable to voluntary work.

5. The outcomes should be able to capture the perspectives of the worker and/or the employer.

6. The outcomes should align with the ICF framework of participation and be operationalized either on the level of capacity or performance (10).

Optional outcome criteria; these criteria should be met where possible and when applicable:

1. The outcome measures should allow for the evaluation of cost-effectiveness of interventions whenever feasible.

2. The outcome should be applicable across varying insurance schemes.

Table 3

Criteria to be met per outcome for a core outcome set for work participation.

Outcomes should Reason

Mandatory criteria

1. Be sensitive to change

Scientifically sound measurements of the effectiveness of vocational or nonvocational interventions which may impact work participation

2. Be feasible to measure $\quad$ COS outcomes should represent a minimum set which is feasible to be measured across all intervention studies

3. Be applicable internationally International comparability of research is important

4. Be work participation There are many participation roles. The worker role is distinct specific

5. Capture multiple stakeholder The worker and/or the employer perspective should be represented as a minimum perspectives

6. Be in alignment with the ICF The ICF is the most frequently used model in research and practice. model

Optional criteria

1. Be used for cost- Cost-effectiveness analysis is important for societal decision making effectiveness studies

2. Be applicable across varying Outcomes should be as relevant as possible irrespective of the varying insurance insurance schemes schemes

\section{E. Framework for work participation outcomes}

Using the ICF we identify four work participation stages that help structure outcomes which are potentially relevant to select in the COS for work participation: 
Stage 1: Initiating employment, Stage 2: Having employment, Stage 3: Increasing or maintaining productivity at work, Stage 4: Return to employment.

Different disease courses and disability trajectories may dictate which stages of work participation the outcome measurements should primarily be focused on, as illustrated in Fig. 3 for five prevalent diseases (79-84) .

Besides the disease status or health problem (chronic, progressive, intermittent, relapsing, resolving) the choice of outcomes is determined by identifying the baseline status of the target group (employed-unemployed, seeking-maintaining-losing work), and the specific intervention types or aims.

\section{Stage 1: Initiating employment.}

Outcomes within this stage help determine whether participants are prepared for initiating employment. ICF categories "apprenticeship" (work preparation)" and "acquiring a job" apply. Interventions for this category focus on increasing skills, knowledge or attitude of participants for successful engagement in a worker-role. The target group is unemployed at baseline (not self-employed or contracted by an employer, but possibly with a type of subsidized governmental wage replacement benefit). Examples of outcomes are readiness for work, motivation for work, job seeking skills (Table 4). The intervention types are commonly vocational, such as Individual Placement and Support programs which help people with a chronic mental health problem to gain work (11).

Table 4

"Initiating employment" work participation stage; examples of target groups, types of interventions and outcomes.

\begin{tabular}{|c|c|c|}
\hline Target group & Intervention types & $\begin{array}{l}\text { Examples of } \\
\text { outcomes }\end{array}$ \\
\hline \multirow[t]{4}{*}{$\begin{array}{l}\text { - Unemployed persons aiming } \\
\text { to get work }\end{array}$} & $\begin{array}{l}\text { - Vocational interventions helping people with a health problem to } \\
\text { gain or employment }\end{array}$ & $\begin{array}{l}\text { - Readiness for } \\
\text { work }\end{array}$ \\
\hline & & $\begin{array}{l}\text { - Motivation for } \\
\text { work }\end{array}$ \\
\hline & & $\begin{array}{l}\text { - Job seeking } \\
\text { skills }\end{array}$ \\
\hline & & $\begin{array}{l}\text { - Job interview } \\
\text { skills }\end{array}$ \\
\hline
\end{tabular}

Stage 2: Having employment.

Outcomes relevant for this stage of work participation indicate whether a person is in employment, can retain employment or loses work within the duration of the study. In general, these outcomes fit in the ICF categories under "remunerative employment" and "keeping a job". Being employed can be considered as having a contract with an employer or being selfemployed. Interventions relevant for this stage are either vocational or non-vocational (Table 5). Vocational rehabilitation studies commonly have a primary aim to determine the effect of the interventions on employment status. Medical or pharmaceutical studies may find it relevant to measure the effect of the intervention on the employment status of their participants besides their primary medical outcomes. The target group of these interventions are people who are known to be at risk of losing employment due to a health problem. For instance, it has been shown that cancer survivorship $(41,85)$, cardiovascular disease and diabetes (86) are associated with higher unemployment rates. 
Table 5

"Having employment" work participation stage; examples of target groups, types of interventions and outcomes.

$\begin{array}{lll}\text { Target group } & \text { Intervention types } & \text { Examples of outcomes } \\ \begin{array}{lll}\text { - Unemployed persons aiming to get } & \text { - Vocational interventions aiming to help people } & \text { - Employment rate } \\ \text { (part/full time) }\end{array} \\ \begin{array}{ll}\text { - Employed persons at risk of losing } \\ \text { employment }\end{array} & \text { - Non- vocational interventions } & \text { - Employment duration } \\ & & \text { - Time to (first) } \\ & \text { employment } & \text { - Job loss } \\ & & \text { - Early retirement due to ill } \\ & \text { health }\end{array}$

Stage 3: Increasing or maintaining productivity at work is a stage of work participation which is relevant when people experience limitations/restrictions with working or have less output. The latter is often used to calculate costs $(62,74)$. In terms of ICF the outcomes could be placed under the "maintaining a job" category. Outcomes are measured for any type vocational or clinical/pharmaceutical intervention which may impact overall productivity, work ability and work functioning for people with a health problem (Table 6). From the worker perspective, feeling fit to work is essential for a successful career. As preventive measures employers can provide interventions aiming to reduce stress and increase wellbeing at work $(87,88)$.

Table 6

"Increasing or maintaining productivity at work" work participation stage; examples of target groups, types of interventions and outcomes.

$\begin{array}{lll}\text { Target group } & \text { Intervention types } & \text { Examples of } \\ \text { outcomes }\end{array}$

- Persons holding a job and experiencing functional problems at work due to a health problem

$\begin{array}{ll}\text { - Non- vocational interventions measuring variables } & \text { - At-work } \\ \text { which may also impact at-work functioning } & \text { productivity } \\ \text { - Vocational interventions providing work related } & \\ \text { rehabilitation } & \text { - Work ability } \\ \text { - Work related vitality interventions } & \text { - Work } \\ & \begin{array}{l}\text { activity } \\ \text { impairment }\end{array} \\ & \text { - Vitality }\end{array}$

Stage 4: Return to employment is a stage of work participation when people (temporarily) stop attending work and are on sick leave. The ICF does not include sickness absence, but potentially outcomes for this stage could fit under "maintaining employment" and "remunerative employment" ICF categories. Work related rehabilitation interventions designed to help workers return to work include outcomes relevant to this stage as their primary outcome. Any type of clinical, pharmaceutical or otherwise health related intervention may be expected to indirectly impact outcomes relevant for this stage (Table 7). Sickness absence can show that a person is unable to fulfil their worker role due to ill health, but other reasons for absenteeism, such as maternity leave or unwillingness to come to work also exist. Evaluation of absenteeism outcomes are often approached from the societal/economic perspectives (89). Importantly, sick leave time can be converted into monetary value as part of economic evaluations to indicate extra costs for the employer or/and the employee. Measuring changes in sick leave data is not straightforward as several epidemiological approaches can be applied $(16,77)$. More recently, the term 'return to work' has been introduced as an indicator of sickness absence with an individual perspective. For individuals, the worker role is important for economic reasons and for reasons of well-being. For example, cancer survivors report that getting back to work is a final step in getting back to normal life after their disease/treatment experience (41). We consider absenteeism and return to work as measures from different perspectives but belonging to the same concept of not working (fully) in spite of having employment. Outcomes for this stage may be: RtW rate, time to RtW, sick leave rate, sick leave 
duration and frequency. In addition, outcomes indicating the perceived capacity to RtW can also apply. For example: intention to RtW, RtW self-efficacy and the need for recovery from work.

Table 7

"Return to employment" work participation stage; examples of target groups, types of interventions and outcomes.

\begin{tabular}{|c|c|c|}
\hline Target group & Interventions types & $\begin{array}{l}\text { Examples of } \\
\text { outcomes }\end{array}$ \\
\hline \multirow[t]{7}{*}{$\begin{array}{l}\text {-Persons holding a job but not working } \\
\text { (fully) due to health reasons }\end{array}$} & $\begin{array}{l}\text { - Non- vocational interventions which may impact } \\
\text { sick leave (clinical, pharmacological) }\end{array}$ & $\begin{array}{l}\text { - Return to work rate } \\
\text { (part/fulltime) }\end{array}$ \\
\hline & $\begin{array}{l}\text { - Vocational interventions aiming to help people get } \\
\text { back to work }\end{array}$ & $\begin{array}{l}\text {-Time to return to } \\
\text { work }\end{array}$ \\
\hline & - Economic evaluations & - Sick leave rate \\
\hline & & - Sick leave duration \\
\hline & & - Intention to RTW \\
\hline & & - RtW self-efficacy \\
\hline & & - Need for recovery \\
\hline
\end{tabular}

\section{F. Feasibility of the framework}

As a proof of concept, we consider six different health problems and interventions of RCT's or a protocol of an RCT (schizophrenia, depression, rheumatoid arthritis, breast cancer, influenza, various health problems causing sick leave). We made this selection as the interventions are vocational and non-vocational addressing issues with different work participation stages and health problems with varying disease progressions.

These interventions should be broadly representative for commonly measured outcomes irrespective of the type of intervention aiming to affect work participation. A fit can be made with what was measured for most criteria of the framework (table 8). However, for criteria 1 and 2 (sensitive to change and feasible to measure), we assumed that the outcomes measured in the studies fulfilled these criteria without having proper evidence from systematic reviews. Ensuring that the outcomes included in the COS will meet these criteria will be part of the further steps in the development of the COS. It is also not clear which outcome measures can be validly used in economic evaluations $(63,74,75)$. Sick leave data is used most often (11) and therefore we assumed that this outcome meets the optional criterion 1 (use of outcome for costeffectiveness analysis). It was not easy to match the outcomes with the ICF. Absenteeism, work ability and productivity do not have designated codes within the ICF, but we mapped them all to the ICF as specified above. Lastly, although we considered it plausible that all outcomes could be applied across varying insurance schemes, this should be further evaluated.

Table 8: Application of criteria for work participation measurement to examples of six diseases with different disability trajectories evaluated in intervention studies 


\begin{tabular}{|c|c|c|c|c|c|c|c|c|c|c|c|c|}
\hline \multirow{2}{*}{$\begin{array}{l}\text { Participants; } \\
\text { Health } \\
\text { condition }\end{array}$} & \multirow{2}{*}{$\begin{array}{l}\text { Participants; } \\
\text { employment } \\
\text { status at } \\
\text { inclusion }\end{array}$} & \multirow[t]{2}{*}{$\begin{array}{l}\text { Work } \\
\text { participation } \\
\text { stage }\end{array}$} & \multirow[t]{2}{*}{ Intervention } & \multirow{2}{*}{$\begin{array}{l}\text { Measured } \\
\text { work } \\
\text { participation } \\
\text { outcomes }\end{array}$} & \multicolumn{6}{|c|}{$\begin{array}{l}\text { Fit with mandatory } \\
\text { criteria }\end{array}$} & \multicolumn{2}{|c|}{$\begin{array}{l}\text { Fit with } \\
\text { optional } \\
\text { criteria }\end{array}$} \\
\hline & & & & & 1 & 2 & 3 & 4 & 5 & 6 & 1 & 2 \\
\hline $\begin{array}{l}\text { Schizophrenia } \\
\text { (90) }\end{array}$ & $\begin{array}{l}17 \% \\
\text { employed }\end{array}$ & $\begin{array}{l}\text { Having } \\
\text { employment }\end{array}$ & $\begin{array}{l}\text { Vocational } \\
\text { rehabilitation }\end{array}$ & $\begin{array}{l}\text { Work status, } \\
\text { work hours }\end{array}$ & $x$ & $x$ & $x$ & $x$ & $x$ & $x$ & & $x$ \\
\hline $\begin{array}{l}\text { Rheumatoid } \\
\text { arthritis (91) }\end{array}$ & $\begin{array}{l}40 \% \\
\text { employed }\end{array}$ & $\begin{array}{l}\text { Increasing } \\
\text { or } \\
\text { maintaining } \\
\text { productivity } \\
\text { at work }\end{array}$ & Pharmaceutical & $\begin{array}{l}\text { Work } \\
\text { productivity }\end{array}$ & $x$ & $x$ & $x$ & $x$ & $x$ & $x$ & & $x$ \\
\hline $\begin{array}{l}\text { Depression } \\
\text { (92) }\end{array}$ & $\begin{array}{l}83 \% \\
\text { employed }\end{array}$ & $\begin{array}{l}\text { Return to } \\
\text { employment }\end{array}$ & $\begin{array}{l}\text { Using self- } \\
\text { assessment of } \\
\text { depression } \\
\text { course during } \\
\text { GP } \\
\text { consultations }\end{array}$ & $\begin{array}{l}\text { Work ability, } \\
\text { sick leave, } \\
\text { time to RtW }\end{array}$ & $x$ & $x$ & $x$ & $x$ & $x$ & $x$ & $x$ & $x$ \\
\hline $\begin{array}{l}\text { Breast cancer } \\
\text { (93) }\end{array}$ & Unspecified & $\begin{array}{l}\text { Return to } \\
\text { employment }\end{array}$ & $\begin{array}{l}\text { Post radiation } \\
\text { exercise } \\
\text { program }\end{array}$ & $\begin{array}{l}\text { Return to } \\
\text { work (sick } \\
\text { leave) }\end{array}$ & $\mathrm{x}$ & $x$ & $x$ & $x$ & $x$ & $x$ & $x$ & $x$ \\
\hline Influenza (94) & $\begin{array}{l}100 \% \\
\text { employed }\end{array}$ & $\begin{array}{l}\text { Return to } \\
\text { employment }\end{array}$ & $\begin{array}{l}\text { Vaccination } \\
\text { against } \\
\text { influenza }\end{array}$ & $\begin{array}{l}\text { Absenteeism } \\
\text { from work }\end{array}$ & $x$ & $x$ & $x$ & $x$ & $x$ & $x$ & $x$ & $x$ \\
\hline $\begin{array}{l}\text { On sick leave } \\
\text { for at least } 6 \\
\text { months due } \\
\text { to any health } \\
\text { problem (95) }\end{array}$ & Employed & $\begin{array}{l}\text { Return to } \\
\text { employment }\end{array}$ & $\begin{array}{l}\text { Independent } \\
\text { medical } \\
\text { evaluation }\end{array}$ & $\begin{array}{l}\text { Absenteeism } \\
\text { from work }\end{array}$ & $x$ & $x$ & $x$ & $x$ & $x$ & $x$ & $x$ & $x$ \\
\hline
\end{tabular}

Mandatory criteria are 1: be sensitive to change, 2: be feasible to measure, 3: be applicable internationally, 4: be work participation specific, 5: capture multiple stakeholder perspectives, 6 : be in alignment with the ICF model. Optional criteria are 1: be used for cost-effectiveness studies, 2: be applicable across varying insurance schemes.

\section{Discussion}

Work participation can best be considered as the engagement in a major life area that is important for most persons and as discharging the worker role. The ICF is a leading framework in defining work functioning, activities and participation, and its counterpart work disability. Terminology of outcomes require critical attention because standardization is lacking. There is no classification of outcomes available that fulfills multiple criteria for a COS on work participation. We propose four comprehensive work participation stages that help to select work outcomes: (1) initiating employment, (2) having employment, (3) increasing or maintaining productivity at work and (4) return to employment.

The studies included in this paper contained theories and findings on what is important to consider for the assessment of work-participation in general $(3,10,17,21,25,28,37,38,40,41,46,71,96)$, and in some cases specifically for an outcome category, such as productivity or sick leave $(60,62)$. Theories as general work-participation process mention a broad range of factors which could be relevant to include in studies which measure improvements in work participation. However, no clear prioritization is indicated on the level of outcomes and consideration of the temporal aspect is often lacking.

We evaluated theories and studies based on empirical findings on what is currently considered as relevant for the assessment of work participation. Our proposed framework is novel in terms of structuring the work participation process on the level of most critical outcomes, including the temporal aspect of various disease courses and progression within the different stages of work-participation. Societal, employer and employee perspectives were taken into consideration. 
Using the proof of concept approach we applied various disease courses and work participation stages reported in trials with varying aims and showed that work participation outcomes fit within our framework. However, the framework suggests a broader scope of outcomes than what trialists may be used to consider. For example, studies on return to work typically do not include outcomes such as "RtW self-efficacy". Looking at literature, such an outcome could be considered for a COS as it could be an important indicator of sustainable RtW. Subjective outcomes are most likely to be under researched and only included in vocational trials (11).

Although we used a sensitive search strategy for our systematic literature review, it is possible that we did not include all theories or frameworks which are also used in research and practice. In addition, our proof of concept is applied to six types of studies which could mean that not all possible outcomes may have been considered.

We will build on the proposed stages of work participation, each with distinct and corresponding types of outcomes, for the further development of a COS. This will involve reaching consensus amongst stakeholders on what type of outcomes are essential to be measured for each stage. Consensus will specifically need to focus on unambiguous outcome definitions for measuring: employment status in stage 2, decreased performance on the job in stage 3 , sickness absence and RtW in category 4 and if subjective outcomes could be relevant for broad use such as motivation for work and RtW self-efficacy. Further, clinimetrically sound measurement methods need to be determined for the set of outcomes, ensuring feasibility for international and cross-disciplinary research.

The COS for Work will enable researchers to compare data on a larger scale and draw better conclusions on which interventions are most effective in promoting work participation. Use of COS will also help reduce research waste and assist policy makers and practitioners in making better informed decisions on worthwhile investments.

\section{Concluding Remarks}

We present a framework for selecting work-participation outcome measurements which will be used for the development of a COS. The framework is presented from the perspective of various stages of the work participation process, and it can be applied to any type of participant population, aim of intervention and by the international community. We propose the following four stages of work participation: (1) initiating employment, (2) having employment, (3) increasing or maintaining productivity at work and (4) return to employment.

\section{Declarations}

\section{Ethics}

Not applicable.

\section{Consent for publication}

Not Applicable.

Availability of data and materials

All data generated or analyzed during this study are included in this published article.

\section{Competing interests}

The authors declare they have no competing interests.

\section{Funding}

No funding to declare. 
Authors' contributions

Study conception and design: all authors; data collection: MR, JV; data analysis: MR, JH, JV; draft manuscript preparation: MR. All authors reviewed the results and approved the final version of the manuscript.

Acknowledgement

SV is supported by Versus Arthritis (grant numbers 20385, 20380) and the NIHR Manchester Biomedical Research Centre.

\section{References}

1. World Health Organization. World report on disability 2011 [cited 2011. Available from: http://www.who.int/disabilities/world_report/2011/en/index.html.

2. Varekamp I, Verbeek JH, van Dijk FJ. How can we help employees with chronic diseases to stay at work? A review of interventions aimed at job retention and based on an empowerment perspective. International archives of occupational and environmental health. 2006;80(2):87-97.

3. Arends I, Bruinvels DJ, Rebergen DS, Nieuwenhuijsen K, Madan I, Neumeyer-Gromen A, et al. Interventions to facilitate return to work in adults with adjustment disorders. Cochrane database of systematic reviews. 2012(12).

4. Hoving JL, Lacaille D, Urquhart DM, Hannu TJ, Sluiter JK, Frings-Dresen MH. Non-pharmacological interventions for preventing job loss in workers with inflammatory arthritis. Cochrane Database of Systematic Reviews. 2014(11).

5. Mateen BA, Doogan C, Hayward K, Hourihan S, Hurford J, Playford ED. Systematic review of health-related work outcome measures and quality criteria-based evaluations of their psychometric properties. Archives of physical medicine and rehabilitation. 2017;98(3):534-60.

6. Schaafsma FG, Whelan K, van der Beek AJ, van der Es-Lambeek LC, Ojajärvi A, Verbeek JH. Physical conditioning as part of a return to work strategy to reduce sickness absence for workers with back pain. Cochrane Database of Systematic Reviews. 2013(8).

7. van Oostrom SH, Driessen MT, de Vet HC, Franche RL, Schonstein E, Loisel P, et al. Workplace interventions for preventing work disability. Cochrane database of systematic reviews. 2009(2).

8. Rosenbaum P, Stewart D, editors. The World Health Organization International Classification of Functioning, Disability, and Health: a model to guide clinical thinking, practice and research in the field of cerebral palsy. Seminars in pediatric neurology; 2004: Elsevier.

9. Escorpizo R, Reneman MF, Ekholm J, Fritz J, Krupa T, Marnetoft SU, et al. A conceptual definition of vocational rehabilitation based on the ICF: building a shared global model. J Occup Rehabil. 2011;21(2):126-33.

10. AlHeresh RA, Keysor JJ. The Work Activity and Participation Outcomes Framework: a new look at work disability outcomes through the lens of the ICF. Int J Rehabil Res. 2015;38(2):107-12.

11. Ravinskaya M, Verbeek JH, Langendam M, Daams JG, Hulshof CT, Madan I, et al. Extensive variability of work participation outcomes measured in randomized controlled trials: a systematic review. Journal of Clinical Epidemiology. 2022;142:60-99.

12. Kirkham JJ, Gargon E, Clarke M, Williamson PR. Can a core outcome set improve the quality of systematic reviews?-a survey of the Co-ordinating Editors of Cochrane Review Groups. Trials. 2013;14(1):21.

13. Williamson PR, Altman DG, Bagley H, Barnes KL, Blazeby JM, Brookes ST, et al. The COMET handbook: version 1.0. Trials. 2017;18(3):280.

14. Tang K, Boonen A, Verstappen SM, Escorpizo R, Luime JJ, Lacaille D, et al. Worker productivity outcome measures: OMERACT filter evidence and agenda for future research. The Journal of Rheumatology. 2014;41(1):165-76.

15. Kirkham JJ, Clarke M, Williamson PR. A methodological approach for assessing the uptake of core outcome sets using ClinicalTrials. gov: findings from a review of randomised controlled trials of rheumatoid arthritis. bmj. 2017;357:j2262.

Page 14/20 
16. Hensing G, Alexanderson K, Allebeck P, Bjurulf P. How to measure sickness absence? Literature review and suggestion of five basic measures. Scand J Soc Med. 1998;26(2):133-44.

17. Amick BC, 3rd, Lerner D, Rogers WH, Rooney T, Katz JN. A review of health-related work outcome measures and their uses, and recommended measures. Spine (Phila Pa 1976). 2000;25(24):3152-60.

18. Lerner D, Amick III BC, Rogers WH, Malspeis S, Bungay K, Cynn D. The work limitations questionnaire. Medical care. 2001:72-85.

19. Young AE, Wasiak R, Roessler RT, McPherson KM, Anema JR, van Poppel MN. Return-to-work outcomes following work disability: stakeholder motivations, interests and concerns. J Occup Rehabil. 2005;15(4):543-56.

20. Beaton D, Bombardier C, Escorpizo R, Zhang W, Lacaille D, Boonen A, et al. Measuring worker productivity: frameworks and measures. J Rheumatol. 2009;36(9):2100-9.

21. World Health Organization. International Classification of Functioning, Disability and Health. Geneva, Switzerland: World Health Organization; 2001.

22. Martins AC. Using the International Classification of Functioning, Disability and Health (ICF) to address facilitators and barriers to participation at work. Work. 2015;50(4):585-93.

23. Anner J, Schwegler U, Kunz R, Trezzini B, de Boer W. Evaluation of work disability and the international classification of functioning, disability and health: what to expect and what not. BMC Public Health. 2012;12:470.

24. Dijkers MP. Issues in the conceptualization and measurement of participation: an overview. Arch Phys Med Rehabil. 2010;91(9 Suppl):S5-16.

25. Nowak LL, Davis AM, Mamdani M, Beaton D, Schemitsch EH. A concept analysis and overview of outcome measures used for evaluating patients with proximal humerus fractures. Disabil Rehabil. 2019:1-13.

26. Hemmingsson $\mathrm{H}$, Jonsson $\mathrm{H}$. An occupational perspective on the concept of participation in the International Classification of Functioning, Disability and Health-some critical remarks. Am J Occup Ther. 2005;59(5):569-76.

27. Glässel A, Finger ME, Cieza A, Treitler C, Coenen M, Escorpizo R. Vocational rehabilitation from the client's perspective using the International Classification of Functioning, Disability and Health (ICF) as a reference. J Occup Rehabil. 2011;21(2):167-78.

28. Resnik L, Plow MA. Measuring participation as defined by the international classification of functioning, disability and health: an evaluation of existing measures. Arch Phys Med Rehabil. 2009;90(5):856-66.

29. Ballert CS, Hopfe M, Kus S, Mader L, Prodinger B. Using the refined ICF Linking Rules to compare the content of existing instruments and assessments: a systematic review and exemplary analysis of instruments measuring participation. Disabil Rehabil. 2019;41(5):584-600.

30. Pransky G. Measurement of outcomes in WDP: Conceptual and methodological considerations and recommendations for measuring outcomes. Handbook of work disability: Springer; 2013. p. 95-106.

31. Sciaraffa S. Identification, Meaning, and the Normativity of Social Roles. European Journal of Philosophy. 2011;19(1):107-28.

32. James WB, Witte JE, Galbraith MW. Havighurst's Social Roles Revisited. Journal of Adult Development. 2006;13(1):5260.

33. Mechanic D. The concept of illness behavior. Journal of chronic diseases. 1962;15(2):189-94.

34. Mechanic D. Sociological dimensions of illness behavior. Social science \& medicine. 1995;41(9):1207-16.

35. Chang FH, Coster WJ. Conceptualizing the construct of participation in adults with disabilities. Arch Phys Med Rehabil. 2014;95(9):1791-8.

36. Finger ME, Escorpizo R, Glässel A, Gmünder HP, Lückenkemper M, Chan C, et al. ICF Core Set for vocational rehabilitation: results of an international consensus conference. Disability and rehabilitation. 2012;34(5):429 - 38.

37. Momsen AH, Stapelfeldt CM, Rosbjerg R, Escorpizo R, Labriola M, Bjerrum M. International Classification of Functioning, Disability and Health in Vocational Rehabilitation: A Scoping Review of the State of the Field. J Occup Rehabil.

Page 15/20 
2019;29(2):241-73.

38. Jetha A, Pransky G, Hettinger LJ. Capturing complexity in work disability research: application of system dynamics modeling methodology. Disabil Rehabil. 2016;38(2):189-94.

39. Mateen BA, Doogan C, Hayward K, Hourihan S, Hurford J, Playford ED. Systematic Review of Health-Related Work Outcome Measures and Quality Criteria-Based Evaluations of Their Psychometric Properties. Arch Phys Med Rehabil. 2017;98(3):534-60.

40. Sternberg A, Bethge M. Measuring work functioning in individuals with musculoskeletal disorders with reference to the International Classification of Functioning, Disability, and Health: a systematic literature review. Int J Rehabil Res. 2018;41(2):97-109.

41. Mehnert A, de Boer A, Feuerstein M. Employment challenges for cancer survivors. Cancer. 2013;119:2151-9.

42. Combs B, Heaton K. Occupational Functionality: A Concept Analysis. Workplace Health Saf. 2016;64(8):385-92.

43. Sandqvist JL, Henriksson CM. Work functioning: a conceptual framework. Work. 2004;23(2):147-57.

44. Goldman HH. Commentary on measuring disability. Arch Phys Med Rehabil. 2013;94(9):1687-9.

45. Marfeo EE, Haley SM, Jette AM, Eisen SV, Ni P, Bogusz K, et al. Conceptual foundation for measures of physical function and behavioral health function for Social Security work disability evaluation. Arch Phys Med Rehabil. 2013;94(9):164552.e2.

46. Berglind $\mathrm{H}$, Gerner U. Motivation and return to work among the long-term sicklisted: an action theory perspective. Disabil Rehabil. 2002;24(14):719-26.

47. Iwanaga K, Chan F, Tansey TN, Strauser D, Ritter E, Bishop M, et al. Working Alliance and Stages of Change for Employment: The Intermediary Role of Autonomous Motivation, Outcome Expectancy and Vocational Rehabilitation Engagement. J Occup Rehabil. 2019;29(2):315-24.

48. Kim S, Rhee S. Measuring the Effects of Employment Protection Policies: Theory and Evidence from the Americans with Disabilities Act. Labour Econ. 2018;54:116-34.

49. Halbesleben JRB, Whitman MV, Crawford WS. A dialectical theory of the decision to go to work: Bringing together absenteeism and presenteeism. Human Resource Management Review. 2014;24(2):177-92.

50. Labriola M. Conceptual framework of sickness absence and return to work, focusing on both the individual and the contextual level. Work. 2008;30(4):377-87.

51. Thulesius HO, Grahn BE. Reincentivizing-a new theory of work and work absence. BMC Health Serv Res. 2007;7:100.

52. Hees HL, Nieuwenhuijsen K, Koeter MW, Bultmann U, Schene AH. Towards a new definition of return-to-work outcomes in common mental disorders from a multi-stakeholder perspective. PLoS One. 2012;7(6):e39947.

53. Pransky G, Gatchel R, Linton SJ, Loisel P. Improving return to work research. J Occup Rehabil. 2005;15(4):453-7.

54. Leyshon R, Shaw L. Using multiple stakeholders to define a successful return to work: a concept mapping approach. Work. 2012;41(4):397-408.

55. Shaw WS, Linton SJ, Pransky G. Reducing sickness absence from work due to low back pain: how well do intervention strategies match modifiable risk factors? J Occup Rehabil. 2006;16(4):591-605.

56. Butler JR, Johnson WG, Baldwin ML. Managing Work Disability: Why First Return to Works is Not a Measure of Success Industrial and Labor Relations Review. 1995;48(3):452-69.

57. Claudi Jensen AG. Towards a parsimonious program theory of return to work intervention. Work. 2013;44(2):155-64.

58. Krause N, Frank JW, Dasinger LK, Sullivan TJ, Sinclair SJ. Determinants of duration of disability and return-to-work after work-related injury and illness: challenges for future research. Am J Ind Med. 2001;40(4):464-84.

59. Verstappen SM, Fautrel B, Dadoun S, Symmons DP, Boonen A. Methodological issues when measuring paid productivity loss in patients with arthritis using biologic therapies: an overview of the literature. Rheumatology (Oxford). 2012;51(2):216-29. 
60. Navarro A, Salas-Nicas S, Llorens C, Moncada S, Molinero-Ruiz E, Morina D. Sickness presenteeism: Are we sure about what we are studying? A research based on a literature review and an empirical illustration. Am J Ind Med.

2019;62(7):580-9.

61. Rainbow JG, Steege LM. Presenteeism in nursing: An evolutionary concept analysis. Nurs Outlook. 2017;65(5):615-23.

62. Koopmanschap M, Burdorf A, Jacob K, Meerding WJ, Brouwer W, Severens H. Measuring productivity changes in economic evaluation: setting the research agenda. Pharmacoeconomics. 2005;23(1):47-54.

63. Jones C, Payne K, Gannon B, Verstappen S. Economic Theory and Self-Reported Measures of Presenteeism in Musculoskeletal Disease. Curr Rheumatol Rep. 2016;18(8):53.

64. Jones C, Verstappen SMM, Payne K. A Systematic Review of Productivity in Economic Evaluations of Workplace Interventions: A Need for Reporting Criteria? Appl Health Econ Health Policy. 2019;17(5):591-613.

65. Mattke S, Balakrishnan A, Bergamo G, Newberry SJ. A review of methods to measure health-related productivity loss. Am J Manag Care. 2007;13(4):211-7.

66. Koopmans L, Bernaards CM, Hildebrandt VH, Schaufeli WB, de Vet Henrica CW, van der Beek AJ. Conceptual frameworks of individual work performance: a systematic review. J Occup Environ Med. 2011;53(8):856-66.

67. Ilmarinen J. Work ability-a comprehensive concept for occupational health research and prevention. Scand J Work Environ Health. 2009;35(1):1-5.

68. Metzinger C, Berg C. Work readiness tools for young adults with chronic conditions. Work. 2015;52(3):605-15.

69. Tengland PA. The concept of work ability. J Occup Rehabil. 2011;21(2):275-85.

70. Jansson I, Björklund A, Perseius KI, Gunnarsson AB. The concept of 'work ability' from the view point of employers. Work. 2015;52(1):153-67.

71. Escorpizo R, Finger ME, Glässel A, Gradinger F, Lückenkemper M, Cieza A. A systematic review of functioning in vocational rehabilitation using the International Classification of Functioning, Disability and Health. J Occup Rehabil. 2011;21(2):134-46.

72. Luna JS, Monteiro GTR, Koifman RJ, Bergmann A. International Classification of Functioning in professional rehabilitation: instruments for assessing work disability. Rev Saude Publica. 2020;54:45.

73. Beaton DE, Dyer S, Boonen A, Verstappen SM, Escorpizo R, Lacaille DV, et al. OMERACT Filter Evidence Supporting the Measurement of At-work Productivity Loss as an Outcome Measure in Rheumatology Research. J Rheumatol. 2016;43(1):214-22.

74. Jones C, Verstappen SM, Payne K. A systematic review of productivity in economic evaluations of workplace interventions: A Need for reporting criteria? Applied health economics and health policy. 2019;17(5):591-613.

75. Gardner BT, Dale AM, Buckner-Petty S, Van Dillen L, Amick III BC, Evanoff B. Comparison of employer productivity metrics to lost productivity estimated by commonly used questionnaires. Journal of occupational and environmental medicine/American College of Occupational and Environmental Medicine. 2016;58(2):170.

76. Hensing G. Swedish Council on Technology Assessment in Health Care (SBU). Chapter 4. Methodological aspects in sickness-absence research. Scand J Public Health Suppl. 2004;63:44-8.

77. Hensing G. The measurements of sickness absence; a theoretical perspective. Norsk Epidemiologi. 2009;19(2):147-51.

78. Pransky G, Himmelstein J. Outcomes research: implications for occupational health. Am J Ind Med. 1996;29(6):573-83.

79. Hakulinen C, McGrath JJ, Timmerman A, Skipper N, Mortensen PB, Pedersen CB, et al. The association between earlyonset schizophrenia with employment, income, education, and cohabitation status: nationwide study with 35 years of follow-up. Social psychiatry and psychiatric epidemiology. 2019;54(11):1343-51.

80. Kalyani RR, Ji N, Carnethon M, Bertoni AG, Selvin E, Gregg EW, et al. Diabetes, depressive symptoms, and functional disability in African Americans: the Jackson Heart Study. Journal of Diabetes and its Complications. 2017;31(8):125965 . 
81. Tamminga SJ, Verbeek JH, de Boer AG, van der Bij RM, Frings-Dresen MH. A work-directed intervention to enhance the return to work of employees with cancer: A case study. Work. 2013;46(4):477-85.

82. Hansen S, Zimmerman P-A, van de Mortel TF. Infectious illness prevention and control methods and their effectiveness in non-health workplaces: an integrated literature review. Journal of infection prevention. 2018;19(5):212-8.

83. Hansen SM, Hetland ML, Pedersen J, Østergaard M, Rubak TS, Bjorner JB. Work ability in rheumatoid arthritis patients: a register study on the prospective risk of exclusion and probability of returning to work. Rheumatology. 2017;56(7):113543.

84. Chi W-C, Yen C-F, Liou T-H, Chang K-H, Liao H-F, Chang Y-L. Exploring factors associated with functional change and predictors of participation improvement-a two years follow-up on people with depression. International journal of environmental research and public health. 2021;18(7):3439.

85. De Boer AG, Taskila T, Ojajärvi A, Van Dijk FJ, Verbeek JH. Cancer survivors and unemployment: a meta-analysis and meta-regression. Jama. 2009;301(7):753-62.

86. Kouwenhoven-Pasmooij T, Burdorf A, Roos-Hesselink J, Hunink M, Robroek S. Cardiovascular disease, diabetes and early exit from paid employment in Europe; the impact of work-related factors. International journal of cardiology. 2016;215:332-7.

87. Abdin S, Welch R, Byron-Daniel J, Meyrick J. The effectiveness of physical activity interventions in improving well-being across office-based workplace settings: a systematic review. Public Health. 2018;160:70-6.

88. Bartlett L, Martin A, Neil AL, Memish K, Otahal P, Kilpatrick M, et al. A systematic review and meta-analysis of workplace mindfulness training randomized controlled trials. Journal of occupational health psychology. 2019;24(1):108.

89. Boccuzzi SJ. Indirect health care costs. Cardiovascular health care economics: Springer; 2003. p. 63-79.

90. Falkum E, Klungsøyr O, Lystad JU, Bull HC, Evensen S, Martinsen EW, et al. Vocational rehabilitation for adults with psychotic disorders in a Scandinavian welfare society. BMC psychiatry. 2017;17(1):1-11.

91. Strand V, Gossec L, Proudfoot CW, Chen C-I, Reaney M, Guillonneau S, et al. Patient-reported outcomes from a randomized phase III trial of sarilumab monotherapy versus adalimumab monotherapy in patients with rheumatoid arthritis. Arthritis research \& therapy. 2018;20(1):1-12.

92. Petersson E, Wikberg C, Westman J, Ariai N, Nejati S, Björkelund C. Effects on work ability, job strain and quality of life of monitoring depression using a self-assessment instrument in recurrent general practitioner consultations: A randomized controlled study. Work. 2018;60(1):63-73.

93. Ibrahim M, Muanza T, Smirnow N, Sateren W, Fournier B, Kavan P, et al. Time course of upper limb function and return-towork post-radiotherapy in young adults with breast cancer: a pilot randomized control trial on effects of targeted exercise program. Journal of Cancer Survivorship. 2017;11(6):791-9.

94. Nichol KL, Lind A, Margolis KL, Murdoch M, McFadden R, Hauge M, et al. The effectiveness of vaccination against influenza in healthy, working adults. New England Journal of Medicine. 1995;333(14):889-93.

95. Husabo E, Monstad K, Holmås TH, Oyeflaten I, Werner EL, Maeland S. Protocol for the effect evaluation of independent medical evaluation after six months sick leave: a randomized controlled trial of independent medical evaluation versus treatment as usual in Norway. BMC Public Health. 2017;17(1):1-6.

96. Dijkers MP, Hart T, Tsaousides T, Whyte J, Zanca JM. Treatment taxonomy for rehabilitation: past, present, and prospects. Arch Phys Med Rehabil. 2014;95(1 Suppl):S6-16.

\section{Figures}


Systematic literature search on theories, definitions and classifications of work participation outcomes

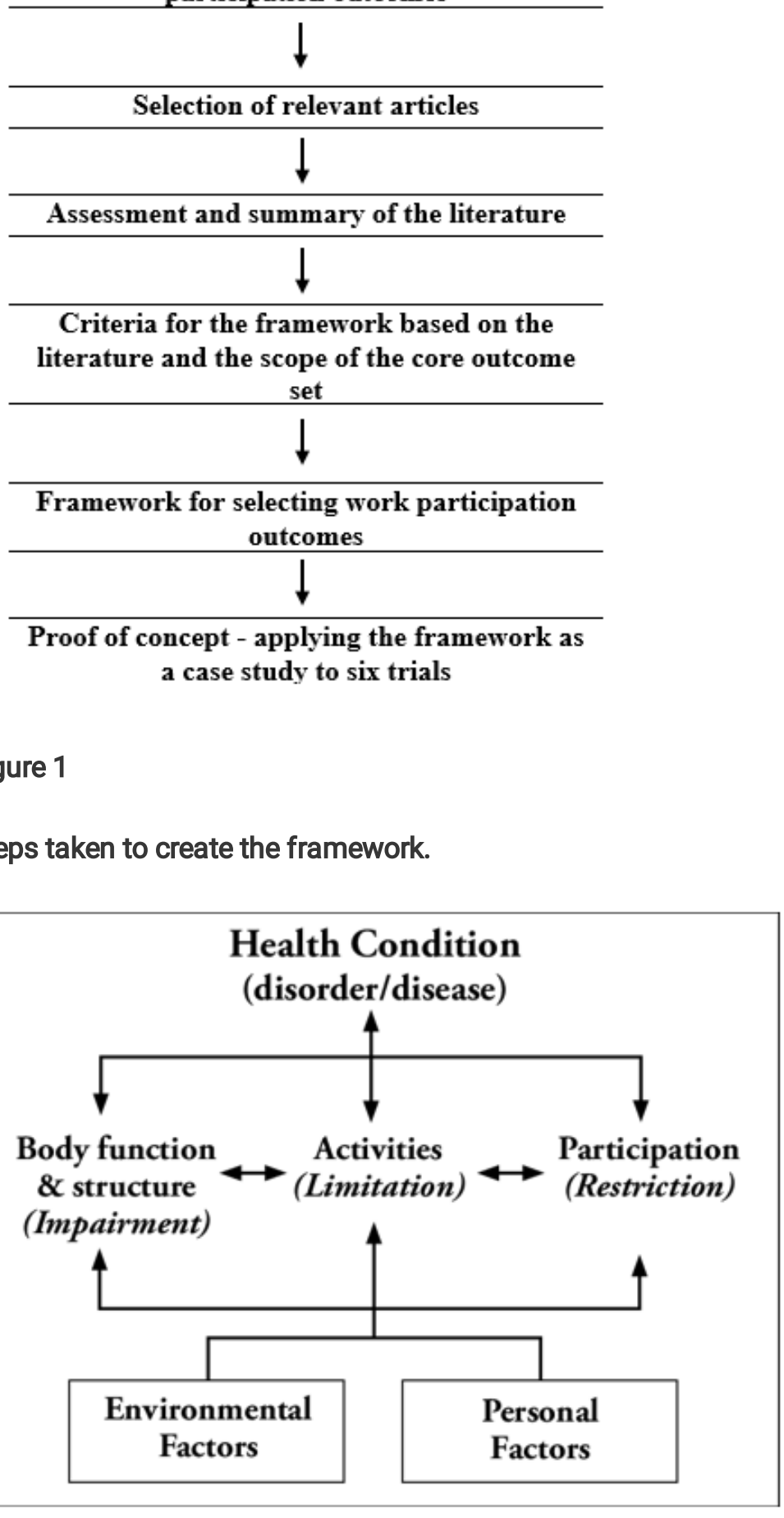

Figure 2

The ICF framework: Interaction between the ICF components (21). 


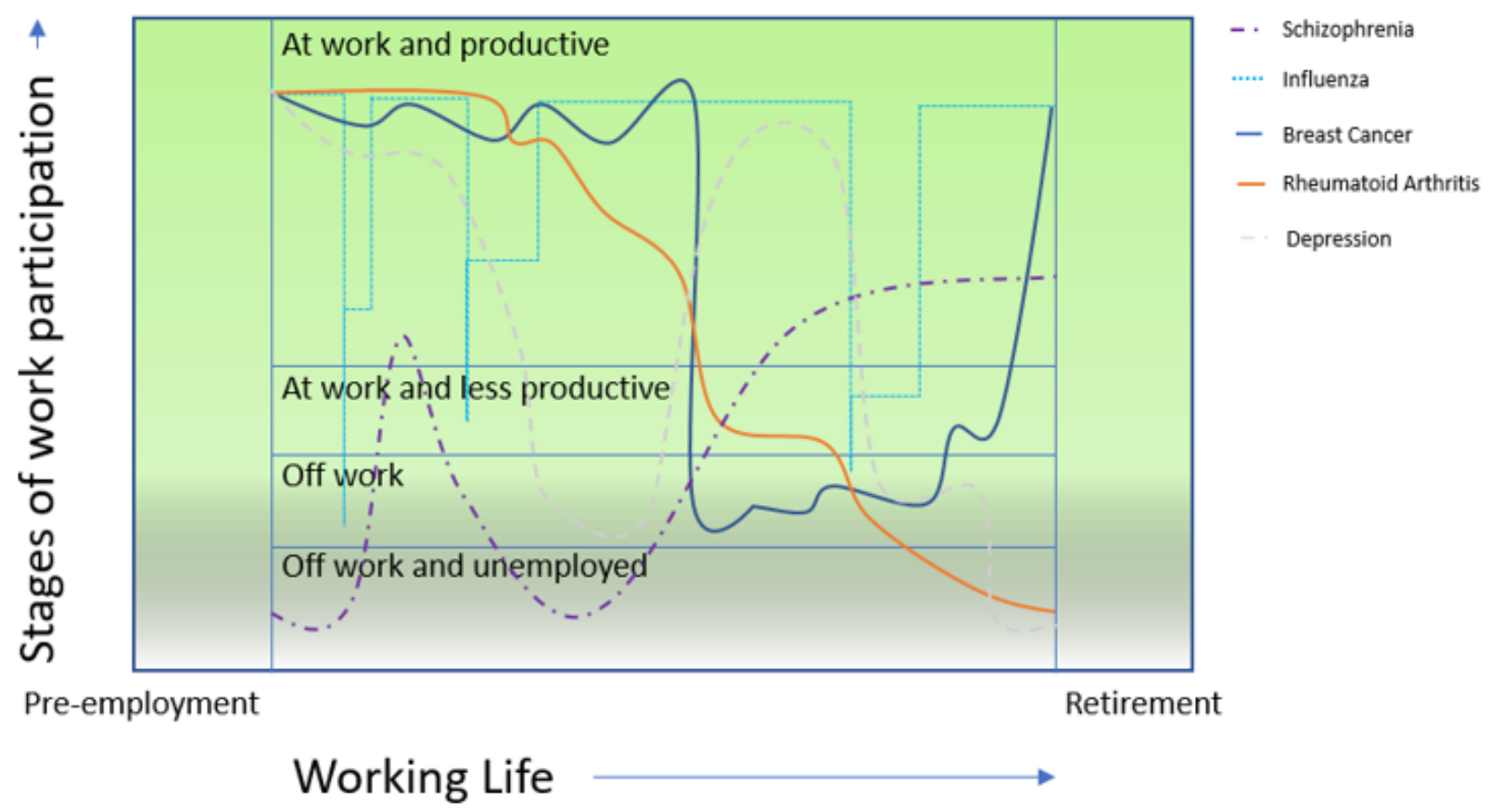

Figure 3

Possible disability trajectories resulting from various health problems. From initiating work until retirement various work participation stages are likely to be experienced. The type of health problem may be an important indicator of interventions aims and relevant outcomes to be measured.

\section{Supplementary Files}

This is a list of supplementary files associated with this preprint. Click to download.

- Appendix1.Searchstrategy.docx 